\title{
NR4A1 wt Allele
}

National Cancer Institute

\section{Source}

National Cancer Institute. NR4A1 wt Allele. NCI Thesaurus. Code C52144.

Human NR4A1 wild-type allele is located in the vicinity of $12 \mathrm{q} 13 \mathrm{ad}$ is approximately $22 \mathrm{~kb}$ in length. This allele, which encodes orphan nuclear receptor NR4A1 protein, is involved in cellular response to hormones. 